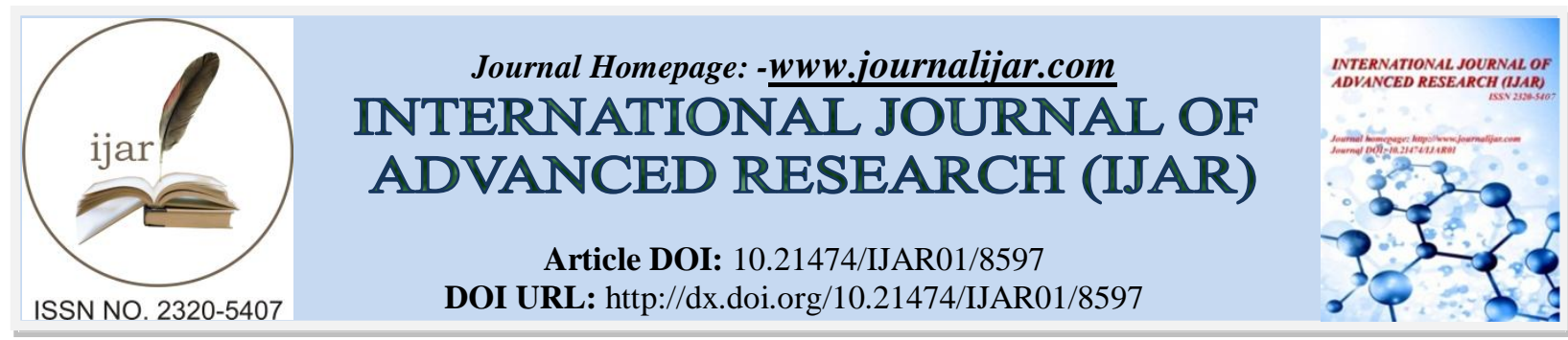

RESEARCH ARTICLE

\title{
PROMOTION OF HEALTH EDUCATION WITH EMPHASIS ON THE IMPORTANCE OF FOOD AND NUTRITIONAL EDUCATION.
}

\author{
Dayane de Melo Barros ${ }^{1}$, Priscilla Gregorio de Oliveira Sousa ${ }^{1}$, Danielle Feijó de Moura ${ }^{1}$, Tamiris Alves \\ Rocha $^{2}$, Marllyn Marques da Silva ${ }^{1}$, André Severino da Silva ${ }^{1}$, Milca de Vasconcelos Gomes ${ }^{3}$, Silvio Assis de \\ Oliveira Ferreira ${ }^{4}$, Roberta de Albuquerque Bento da Fonte ${ }^{5}$
}

1. Mestre em Saúde Humana e Meio Ambiente - Centro Acadêmico de Vitória, Universidade Federal de Pernambuco, CAV/UFPE - Pernambuco, Brasil.

2. Doutora em Ciências Biológicas - Universidade Federal de Pernambuco, UFPE - Pernambuco, Brasil.

3. Fisioterapeuta - Centro Universitário Tabosa de Almeida, Asces-Unita - Pernambuco, Brasil.

4. Mestre em Bioquímica e Fisiologia - Universidade Federal de Pernambuco, UFPE - Pernambuco, Brasil.

5. Doutora em Nutrição - Universidade Federal de Pernambuco, UFPE - Pernambuco, Brasil.

\section{Manuscript Info}

\section{Manuscript History}

Received: 02 January 2018

Final Accepted: 04 February 2019

Published: March 2019

Key words:-

Children, education, food, healthy, school.

\section{Abstract}

One of the most important characteristics related to the development and growth of school-age children is food. As the children begin their studies, there is a great socialization, with a greater susceptibility to reproduction of the behavior of the like. In this way, it is necessary, to stimulate in groups, a healthier diet. For this, it is fundamental to add nutritional education in education, since it acts as an excellent resource for health promotion through the formation of healthy food preferences, influencing changes related to the practices and actions of daily children. Based on this, the present study aimed to promote an action of health education highlighting the importance of food and nutritional education in a public school located in Vitória de Santo Antão Pernambuco. The study was carried out through authorization through the WICF for those under 18 years of age. The nutritional education activity was carried out with 30 students from the 5 th grade. Before the nutritional education activity, the students attended a class on healthy eating. Then there was an activity of how to assemble a healthy dish. After the activity, it was observed that the students were able to integrate with the proposed action, presenting interest on the subject addressed, due to the application of the developed ludic-pedagogical practice. Thus, the activity performed was of significant importance for the students' learning. Emphasizing that this type of educational action allowed the children to transmit new knowledge acquired about healthy eating for their family and purposes, and also demonstrated the need to apply nutritional education in school.

Copy Right, IJAR, 2019,. All rights reserved. 


\section{Introduction:-}

Food is considered one of the most relevant environmental aspects associated with the development and growth of children during school age (BERNART and ZANARDO, 2001). School age is between 7 and 10 years of age, representing in turn a period of growth which requires high nutrient requirements (FAGIOLI, 2006). While children begin to attend school, a broad socialization is initiated that will lead to new influences, resulting in a greater tendency to reproduce behaviors similar to those of educators and other children. Thus, it is necessary to instigate a healthy and nutrient-rich diet in a group (SOUZA, 2006). Therefore, it is important to include nutritional education in education. According to Resolution No. 380/2005 of the Federal Council of Nutritionists (FCN), Food and Nutrition Education (FNE) is defined as "The procedure performed by the nutritionist with individuals or population groups, considering the interactions and meanings that make up the phenomenon of food behavior, to advise changes necessary to a re-adjustment of eating habits". In view of this, the application of EAN in schools is an important instrument for promoting health through the formation of healthy food preferences, implying changes related to the daily practices and actions of individuals (SILVA and FONSECA, 2009; SOUZA, 2006). In addition, the approach to nutrition and feeding in the school context is intended to raise a critical awareness of the need to make better food choices, or even to try to modify the food preferences that are aimed at an industrialized diet seeking with introduce the most natural feed possible (SOUSA, 2006). The present study aimed to promote an action of health education highlighting the importance of food and nutritional education in the Major Manoel Fortunato school in Vitória de Santo Antão-Pernambuco.

\section{Methodology:-}

The study was carried out through authorization through the Written Informed Consent Form (WICF) for minors under 18, resolution 466/12. The nutritional education activity was developed with 30 students from the 5 th year of elementary school I, presenting a mean age of 10 years. Prior to the nutritional education activity, students attended a class on healthy eating (Figure 1).

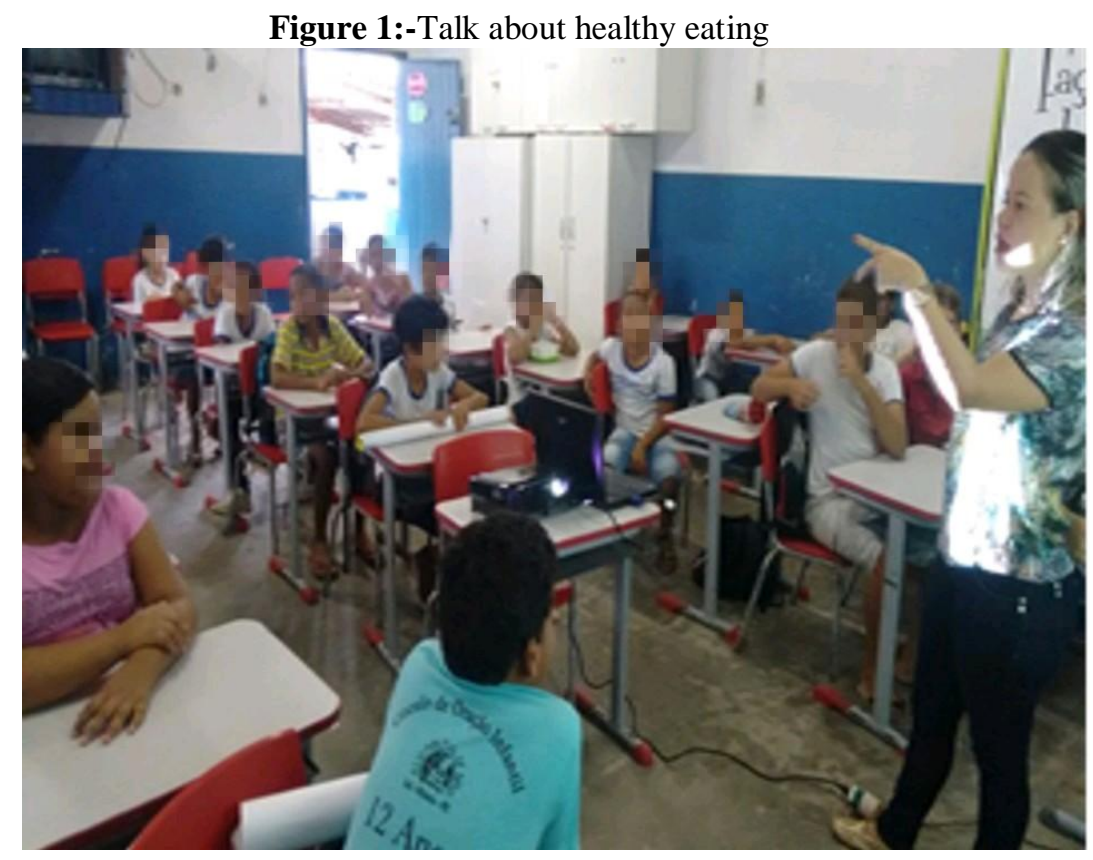

Subsequently, an activity was proposed on how to assemble a healthy dish using an empty styrofoam plate and taken to the classroom cuts of several printed figures of foods normally consumed at lunch. After this, schoolchildren glued the food figures (Figure 2) more discussed during healthy eating class, receiving guidance on how to make appropriate choices. 


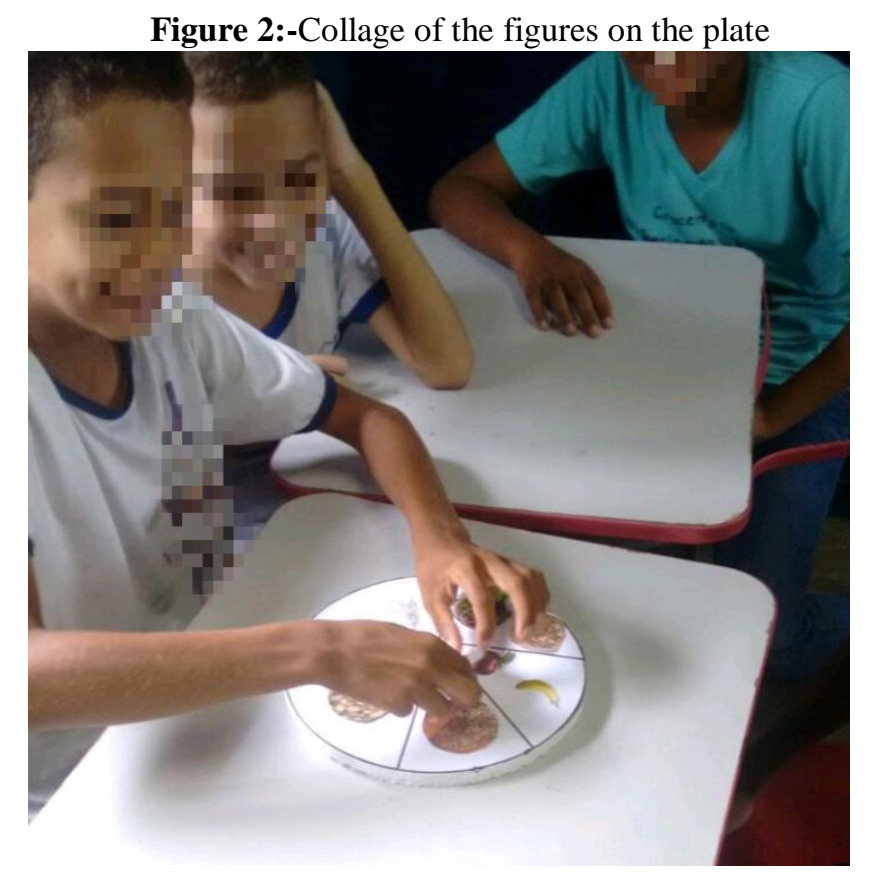

\section{Results:-}

After the application of the nutritional education promotion activity, it was observed that the students were able to integrate with the proposed action, presenting interest while, it occurred to the explanation about food. The studies also questioned when they had doubts, collaborating with the arguments proposed for the assembly of a lunch. And they demonstrated through the activity a healthy and diversified meal (Figure 3).

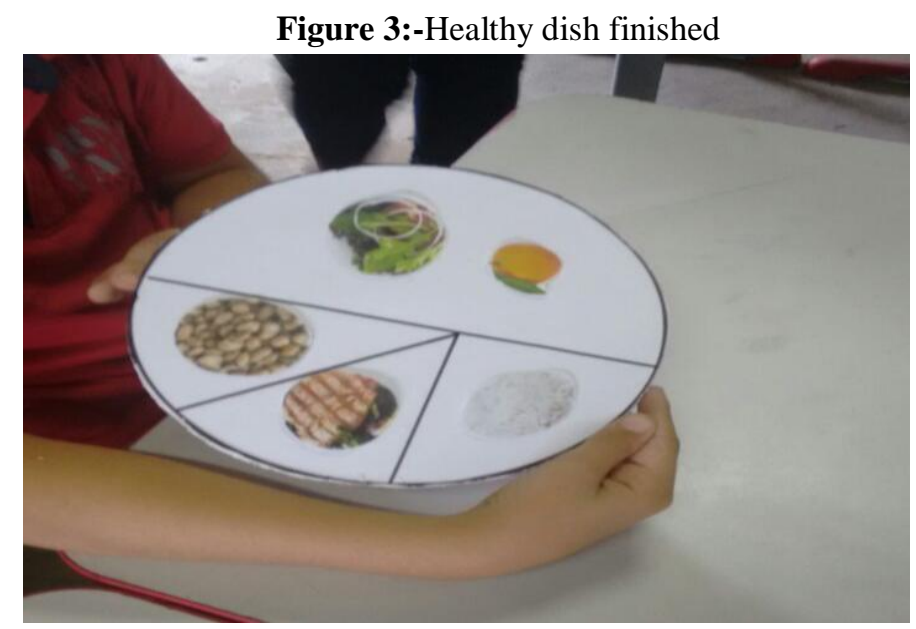

\section{Conclusion:-}

The nutritional education activity carried out was of significant importance for students' learning about healthy eating habits because, as children understand the nutritional value of food, it becomes easier to transition to their food preferences during the period school. It was also observed that the students showed great interest in an adequate nutritional diet. In view of this, it was shown that the activity carried out also allowed the children to transmit the new knowledge acquired about healthy food for their family and the like. The activity carried out resulted in an excellent educational action, which is easy to apply and analyze, generating the interest and creativity of the students in relation to balanced and adequate nutritional food choices. In addition, the study contributed to show the need for the insertion of nutritional education in the school context. 


\section{References:-}

1. BERNART, A.; ZANARDO, V. P. S. Educação nutricional para crianças em escolas públicas de Erechim/RS. Vivências, v.7, n.13, p.71-79, 2011.

2. BRASIL. RESOLUÇÃO CFN N ${ }^{\circ} 380 / 2005$. Dispõe sobre a definição das áreas de atuação do nutricionista e suas atribuições, estabelece parâmetros numéricos de referência, por área de atuação, e dá outras providências, 2005.

3. FAGIOLI, D. Educação nutricional na infância e na adolescência: planejamento, intervenção, avaliação e dinâmicas. São Paulo: RCN Editora, 2006.

4. SILVA, E. C. R.; FONSECA, A. B. Abordagens pedagógicas em educação alimentar e nutricional em escolas no Brasil. In: ENCONTRO NACIONAL DE PESQUISA EM ENSINO DE CIÊNCIAS (ENPEC), 7., 2009, Florianópolis. Anais... Florianópolis: ABRAPEC, 2009.

5. SOUSA, P.M.O. Alimentação do pré-escolar e escolar e as estratégias de educação nutricional. 62f. 2006. Especialização (Qualidade de Alimentos), Universidade de Brasília, Brasília, 2006. 